\title{
Plant Growth Promoting Rhizobacteria (PGPR): A Sustainable Agriculture to Rescue the Vegetation from the Effect of Biotic Stress: a Review
}

\author{
Anmol Gupta ${ }^{1(\mathbb{D})}$, Ambreen Bano ${ }^{1(\mathbb{D})}$, Smita Rai ${ }^{1(\mathbb{D})}$, Priya Dubey ${ }^{2(\mathbb{D})}$, Fahad Khan ${ }^{3(\mathbb{D})}$, Neelam \\ Pathak $^{4, *(D)}$, Swati Sharma ${ }^{1, *(D)}$ \\ 1 Plant Microbe Interaction and Molecular Immunology Laboratory-IIRC-3., Department of Biosciences, Integral \\ University, Lucknow, UP, India; anmolgupta632@gmail.com (A.G.), ambreenbano2408@gmail.com (A.B.), \\ shiblyrai@gmail.com (S.R.), sw_sh@rediffmail.com (S.S.); \\ 2 Department of Environment Sciences, CSIR-National Botanical Research Institute, Lucknow, India; \\ priyadubeyd@gmail.com (P.D.); \\ 3 Department of Biotechnology, Noida Institute of Engineering \& Technology, Greater Noida, India; \\ fahadintegralian@gmail.com (F.K.); \\ 4 Department of Biochemistry, Dr. RML Awadh University, Ayodhya, UP, India.; pathak.neelam007@ gmail.com (N.P.); \\ * Correspondence: sw_sh@rediffmail.com (S.S.); pathak.neelam007@gmail.com (N.P.);
}

Scopus Author ID 57198535273

Received: 28.11.2020; Revised: 5.01.2021; Accepted: 11.01.2021; Published: 19.01.2021

\begin{abstract}
Many biotic agents such as bacteria, viruses, nematodes, arachnids, and weeds encounter the plants. These entities induce biotic stress in their hosts with the aid of disrupting normal metabolism, resulting in limited plant growth and causing plant mortality. As Arbuscular Mycorrhizal Fungi (AMF), plant-associated microbes can regulate physiological and molecular responses to cope with pathogenic biotic stress via enhanced antioxidant defense systems and mitigate oxidative stress. Several microbes can benefit plant growth and perform a similar role as pesticides and chemical fertilizers, acting as a biofertilizer and biopesticide. Plant growth-promoting rhizobacteria (PGPR) can expressively heighten plant growth and represent a mutually helpful plant-microbe interaction by facilitating the surroundings' nutrient uptake. The rhizobacteria such as Bacillus sp. can form spores that help them survive for a long period under harsh environmental conditions. PGPR can augment plant growth by introducing induced systemic resistance, antibiosis, and competitive omission and resisting the plants against biotic agents. Bacillus subtilis exhibits both a direct and indirect biocontrol mechanism to suppress disease and provide resistivity towards pathogenic pests caused by pathogens. These mechanisms assist the plant in its protection from the pathogenic onset. The present review discusses Plant Growth-Promoting Rhizobacteria's biocontrol potential and its role as a root colonizer. The associated biocontrol mechanisms of these PGPR to increase crop productivity under biotic stress conditions.
\end{abstract}

Keywords: stress; PGPR; AMF; bio-control mechanism; crops.

(C) 2020 by the authors. This article is an open-access article distributed under the terms and conditions of the Creative Commons Attribution (CC BY) license (https://creativecommons.org/licenses/by/4.0/).

\section{Introduction}

Field pea (Pisum sativum L.) one of the most important annual legume crops. Pisum sativum $L$. is an annual food legume of the Fabaceae family (formerly known as the Leguminosae). Uttar Pradesh alone produces about $49 \%$ of pea produced in India. Besides, Uttar Pradesh, Madhya Pradesh, Bihar, and Maharashtra are the major pea producing states (DES, 2015-16). The production and its productivity are far below the potential; it is due to 'stress'. Stress refers to any external factor that negatively influences the metabolism, growth, 
productivity, and ultimately survival of the plants. Stress can be defined as any factor which harms plant growth and development [1]. Fungal diseases have gained importance for several decades as they cause huge loss of yield to the legumes. Fusarium spp. and F. oxysporum are the most important obstacles for the enhanced production of legumes [2], causing chlorosis or yellowing of leaf, wilting, and crop death. The causal organism is the Erysiphe species, an important fungus causing approximately $40 \%$ yield loss in legumes [3]. Powdery mildew is a common disease in pea. Aphanomyces is another type of fungal pathogen present in the soil causing root rot in leguminous plants. Currently, due to the use of many synthetic products such as mineral fertilizers, insecticides, fungicides, herbicides, etc., in agriculture, causing the community health problem. Thus, contaminating the groundwater and harvested products. So, it is urgent to find alternative agricultural practices. In this perspective, the use of bioresources such as Plant Growth-Promoting Rhizobacteria (PGPR) can benefit plant growth because of their considerable agronomic advantage. PGPR is a group of micro-organisms that actively colonize plant roots and promote plant growth and yield. They are important in managing plant growth because of their effects on soil conditions, nutrient availability, growth, and yields. PGPR can produce antibacterial and antifungal compounds, which can effectively oppose certain plant pathogens and pests [4,5]. PGPR indirectly mediates biological control by eliciting Induced Systemic Resistance (ISR) against many plant diseases [6]. Several different bacteria promote plant growth, including Acetobacter sp., Azotobacter sp., Azospirillum sp., Pseudomonas sp., and, Bacillus sp. Also, it was observed to lead to induced systemic resistance in the treated plant [7]. This study aims to understand the beneficial effect of these PGPR isolates on plant growth under biotic stress conditions.

\section{Stress}

Stress is defined as a phenomenon that limits crop growth, affects productivity, or destroys biomass [8]. Environmental stresses are of two types as (1) Biotic stress and (2) Abiotic stress. Abiotic stress includes drought, salinity, heat, flooding, cold, heavy metals exposure, nutrient deficiency, etc. Biotic stress in plants is caused by living organisms, especially bacteria, fungi, viruses, nematodes, insects, and weeds. These biotic agents directly deprive their host of their nutrients can lead to the death of plants. Biotic stress can cause deleterious effects because of pre and post-harvest losses. Many biotic stresses affect Photosystems and reduce the rate of photosynthesis per leaf area. Therefore to overcome the biotic and abiotic stress, various PGPRs perform an important mechanism (Table 1). Pea crops are highly prone to bacterial, viral, and fungal diseases.

\subsection{Disease caused by Fusarium oxysporum on plants.}

Fungal diseases have gained importance for several decades as they cause huge loss of yield to the legumes. Powdery mildew is a serious disease influencing pea crops. The causal organism is the Erysiphe species, a vital fungus causing approximately $40 \%$ yield loss in legumes [3]. Several fungi can cause diseases on plants, but the most worrying one is the Fusarium oxysporum (soil-borne fungus) which interact with plant tissue causing adverse effect. The pathogenic strains were further subdivided into races according to their cultivar specificity [19]. More than 150 formae speciales and races are presently described. The $F$. oxysporum host flora encircles some of the most estimable ornamental plants, such as Chrysanthemum spp. Dianthus spp., Gerbera spp., Gladiolus spp. and Lilium spp. [20,21]. 
Table 1. Potential role and mechanism of PGPR under Biotic and Abiotic stress tolerance.

Biotic Stress

\begin{tabular}{|c|c|c|c|c|}
\hline S.No. & Pathogen & PGPR & Mechanism associated with the tolerance & Ref. \\
\hline \multirow[t]{3}{*}{1.} & Botrytis cinerea & Bacillus subtilis (PTA-271) & $\begin{array}{ll}\text { (i) } & \text { Induced the oxidative burst. } \\
\text { (ii) } & \text { Accumulated the stress-related } \\
\text { phytoalexin metabolites (trans- } & \text { resveratrol and trans- } \varepsilon \text {-viniferin). } \\
\text { (iii) } & \text { Regulated the defense-related gene } \\
& \text { expression in shoot and root, including } \\
& \text { those with transcriptional factor } \\
& \text { functions (ACCsyn, GST, CHS, CHI), } \\
& \text { and PR proteins (PR1, PR2, PR3, PR5, } \\
& \text { and PR6). }\end{array}$ & [9] \\
\hline & & $\begin{array}{l}\text { B. subtilis } \quad(\mathrm{BBG} 127, \\
\text { BBG131 Bs2504, and } \\
\text { BBG125) }\end{array}$ & $\begin{array}{l}\text { (i) By non-producing lipopeptides. } \\
\text { (ii) Overproducing surfactin. }\end{array}$ & {$[10]$} \\
\hline & & Streptomyces anulatus S37 & $\begin{array}{l}\text { (i) Induced defenses modulated by } \\
\mathrm{Ca} 2+\text { signaling. }\end{array}$ & {$[11]$} \\
\hline 2. & $\begin{array}{l}\text { Flavescence dorée } \\
\text { phytoplasma }\end{array}$ & Pseudomonas migulae 8R6 & $\begin{array}{l}\text { (i) Production of 1-aminocyclopropane-1- } \\
\text { carboxylate (ACC) deaminase enzyme helps the } \\
\text { plant regulate the stress-related hormone ethylene } \\
\text { level. }\end{array}$ & [12] \\
\hline \multicolumn{5}{|c|}{ Abiotic Stress } \\
\hline 3. & Salinity stress & $\begin{array}{l}\text { Bacillus amyloliquefaciens } \\
\text { SB-9 }\end{array}$ & $\begin{array}{l}\text { (i) By upregulating the melatonin biosynthesis and } \\
\text { their intermediates, and downregulation of a } \\
\text { serotonin N-acetyltransferase gene (SNAT) and } \\
\text { grapevine tryptophan decarboxylase genes (TDCs). } \\
\text { (ii) Reduction of reactive oxygen species (H2O2 and } \\
\text { O2-) in roots. }\end{array}$ & [13] \\
\hline 4. & Drought stress & $\begin{array}{ll}\text { P. fluorescens } & \text { Rt6M10 and } \\
\text { Bacillus } & \text { licheniformis } \\
\text { Rt4M10 } & \\
\end{array}$ & $\begin{array}{l}\text { (i) Induced biosynthesis of monoterpenes and } \\
\text { sesquiterpenes. }\end{array}$ & {$[14]$} \\
\hline 5. & Chilling & B. phytofirmans strain PsJN & $\begin{array}{l}\text { (i) Increased stress-related metabolites such as } \\
\text { aldehydes, malondialdehyde, phenolics, and proline). } \\
\text { (ii) Enhanced the rate of photosynthesis and starch } \\
\text { deposition. } \\
\text { (iii) Induced the expression of the defense-related } \\
\text { genes: StSy, PAL, Chit } 4 c \text {, Chit1b, Gluc, and LOX. }\end{array}$ & $\begin{array}{l}{[15,1} \\
6]\end{array}$ \\
\hline 6. & $\begin{array}{l}\text { Arsenic } \\
\text { contamination }\end{array}$ & $\begin{array}{l}\text { Micrococcus luteus, } \\
\text { B. licheniformis, } \\
\text { P. fluorescens }\end{array}$ & $\begin{array}{l}\text { (i) Increased the antioxidant enzyme activity (APX- } \\
\text { Ascorbate peroxidase; CAT-Catalase; and POX- } \\
\text { Peroxidases). } \\
\text { (ii) Reduced lipids peroxidation in a membrane } \\
\text { (reduced malondialdehyde content) and damaged the } \\
\text { photosystems in the presence of Arsenic. }\end{array}$ & [17] \\
\hline 7. & $\begin{array}{l}\text { High temperature } \\
\text { and drought stress }\end{array}$ & 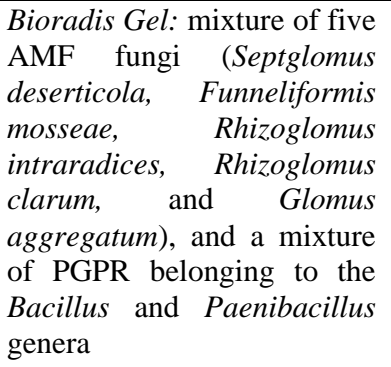 & $\begin{array}{l}\text { (i) Under higher temperature and deficit irrigation, } \\
\text { inoculated plants reached higher berry anthocyanins } \\
\text { \& some modifications in berry ABA catabolism. }\end{array}$ & [18] \\
\hline
\end{tabular}

\subsection{Root colonization and bio-control activity.}

The Rhizosphere is a thin layer of soil directly surrounding the root system [22]. Colonization of roots by Bacillus subtilis is beneficial to both the bacterium and the host plant. Approximately $27 \%$ of the fixed carbon produced by plants is secreted through root exudates. Its percentage can vary with different vegetation [23]. Biological control, utilizing beneficial microbes, is a tremendous method for limiting disease-causing microbes' detrimental impact on plant health and productivity, thereby enhancing agricultural productivity [24]. Some of the Bacillus species are recognized as safe bacteria as they produce a substance that is beneficial for crops [25]. They also produce endospores, which help the bacteria survive under harsh 
environmental conditions, allow for germination by different environmental cues, allow for long-term storage of the biocontrol agent, and reduce the formulation process's complexity [26].

2.3. Synergistic interaction of Arbuscular Mycorrhizal Fungi (AMF) with Bacillus species stimulates plant growth.

Most of the Bacillus species directly stimulate plant growth through enhancement in the nutrient acquisition and stimulate the host plant's defense mechanisms before infection. They can also enhance plant growth by association with AMF [27]. The effect of PGPR Bacillus polymyxa, AMF Glomus intraradices, Pseudomonas putida, and Azotobacter chroococcum on Stevia rebaudiana was also studied [28]. The results confirmed elevated effects due to inoculants' dual compatible mixtures resulting from their strong synergistic relationship among themselves (Table 2) [29].

Table 2. Possible mode of action involved in bacterial-fungal interactions.

\begin{tabular}{c|l|l|l|l} 
S.No. & Fungal partner & Associated bacteria & Mode of Action & References \\
\hline 1. & AM fungi & $\begin{array}{l}\text { Rhizobium leguminosarum; } \\
\text { Azospirillum brasilense; } \\
\text { Streptomyces sp. }\end{array}$ & $\begin{array}{l}\text { Physical attachment; electrostatic attraction; } \\
\text { extracellular polymers; Change in pH; } \\
\text { Production of volatile compounds (VOC) }\end{array}$ & {$[30-32]$} \\
\hline 2. & Agaricus bisporus & Pseudomonas putida & Removes the self-inhibiting compounds & {$[33]$} \\
\hline 3. & Basidiomycetous fungi & Pseudomonads & Fungal exudates & {$[34]$} \\
\hline 4. & Tuber brochii & Pseudomonas fluorescens & Chitinolytic weakening of spore wall & {$[35]$} \\
\hline 5. & Lyophyllum karsten & Burkholderia terrae & Through Biofilm formation & {$[34]$}
\end{tabular}

\subsection{Induction of host resistance and plant growth.}

B. subtilis is a species of PGPR that are known to activate plant host defense response (host resistance) against pathogens. $B$. subtilis is known to activate induced systemic resistance (ISR) in the hosts that they occupy, which increases host resistance to plant pathogens. The activation of ISR by B. subtilis is known to induce the synthesis of Jasmonic acid (JA), ethylene, and the (Non-Expressor of Pathogenesis-related genes 1) NPR1-regulatory gene in plants [36]. Bacillus subtilis help in enhancing the stress tolerance in the plant by inducing the expression of various stress-responsive genes, stress-related metabolites, and phytohormones. These defense responses are conferring the level of disease resistance against bacteria, viruses, and fungi throughout the plant [37]. Many PGPRs has led to increased disease resistance by lowering pathogenic infections.

\subsection{Role of PGPR as a plant growth enhancer.}

PGPR enhances plant growth due to specific traits [38]. PGPR enhances plant growth through direct and indirect mechanisms, which involve enhancing plant physiology and provide resistance to different phytopathogens through various modes and actions [39]. These include nutrient fixation, neutralizing biotic and abiotic stress, and producing Volatile Organic Compounds (VOCs) and enzymes to prevent disease. Many PGPRs can increase the antioxidants enzyme, thus preventing the plant cell from the oxidative burst $[9,40]$. The antioxidant production due to fungus exposure was best studied in budding yeast (Saccharomyces cerevisiae), and oxidative information was reviewed in earlier details [41]. They are influenced by several biotic factors (plant genotypes, plant developmental stages, plant defense mechanisms, and other microbial communities). Many abiotic factors (soil composition, soil management, and climatic conditions) also influence these PGPRs [42]. 


\section{Conclusions}

The selection of bio inoculants as a PGPR manages the pathogen more effectively. This advancement adds sustainable control to controlling the pathogens and provides a defense mechanism by ISR. The recent plant-microbe interaction approaches have paved a protective role under biotic stress and show the biocontrol activity against pathogenic fungus. Further on, colonization and potential interactions also increase the efficiency of PGPB. Arbuscular Mycorrhizal Fungi (AMF) presence could modify root architecture, promote root growth, boost nutrient acquisition, and enhance plant growth performance. Hence, the selection of compatible microbial inoculums is an essential step before initiating any inoculation program and could help the recovery of pathogenic-degraded areas.

\section{Funding}

This research received no external funding.

\section{Acknowledgments}

The authors are grateful to the Department of Science and Technology, New Delhi, for providing financial support (DST INSPIRE-IF160803).

\section{Conflicts of Interest}

The authors declare no conflict of interest.

\section{References}

1. Gupta, A. Effect of PGPR isolates on Plant growth promotion in relation to salinity stress. Bull. Env.Pharmacol. Life Sci 2019, 8, 18-26.

2. Hamwieh, A.; Udupa, S.M.; Choumane, W.; Sarker, A.; Dreyer, F.; Jung, C.; Baum, M. A genetic linkage map of Lens sp. based on microsatellite and AFLP markers and the localization of fusarium vascular wilt resistance. Theor Appl Genet 2005, 110, 669-677, https://doi.org/10.1007/s00122-004-1892-5.

3. Sillero, J.C.; Fondevilla, S.; Davidson, J.; Vaz Patto, M.C.; Warkentin, T.D.; Thomas, J.; Rubiales, D. Screening techniques and sources of resistance to rusts and mildews in grain legumes. Euphytica 2006, 147, 255-272, https://doi.org/10.1007/s10681-006-6544-1.

4. Herman, M.A.B.; Nault, B.A.; Smart, C.D. Effects of plant growth-promoting rhizobacteria on bell pepper production and green peach aphid infestations in New York. Crop Prot 2008, 27, 996-1002, https://doi.org/10.1016/j.cropro.2007.12.004.

5. Minorsky, P.V. On the Inside. Plant Physiol 2008, 146, 1020-1021, https://doi.org/10.1104/pp.104.900251.

6. Handan Altinok, H.; Nilüfer Yildiz, H. Induced Systemic Resistance by Plant Growth-Promoting Rhizobacteria in control of plant diseases. Curr Trends Nat Sci 2019, 8.

7. Kloepper, J.W.; Rodríguez-Kábana, R.; Zehnder, G.W.; Murphy, J.F.; Sikora, E.; Fernández, C. Plant rootbacterial interactions in biological control of soilborne diseases and potential extension to systemic and foliar diseases. Australas Plant Pathol 1999, 28, 21-26, https://doi.org/10.1071/AP99003.

8. Grime, J.P. Plant strategies and vegetation processes. Plant Strateg Veg Process 1979.

9. Gruau, C.; Trotel-Aziz, P.; Villaume, S.; Rabenoelina, F.; Clement, C.; Baillieul, F.; Aziz, A. Pseudomonas fluorescens PTA-CT2 triggers local and systemic immune response against botrytis cinerea in grapevine. Mol Plant-Microbe Interact 2015, 28, 1117-1129, https://doi.org/10.1094/MPMI-04-15-0092-R.

10. Farace, G.; Fernandez, O.; Jacquens, L.; Coutte, F.; Krier, F.; Jacques, P.; Clément, C.; Barka, E.A.; Jacquard, C.; Dorey, S. Cyclic lipopeptides from Bacillus subtilis activate distinct patterns of defence responses in grapevine. Mol Plant Pathol 2015, 16, 177-187.

11. Vatsa-Portugal, P.; Aziz, A.; Rondeau, M.; Villaume, S.; Morjani, H.; Clément, C.; Ait Barka, E. How Streptomyces anulatus Primes Grapevine Defenses to Cope with Gray Mold: A Study of the Early Responses of Cell Suspensions. Front Plant Sci 2017, 8, https://doi.org/10.3389/fpls.2017.01043.

12. Gamalero, E.; Marzachì, C.; Galetto, L.; Veratti, F.; Massa, N.; Bona, E.; Novello, G.; Glick, B.R.; Ali, S.; Cantamessa, S.; D’Agostino, G.; Berta, G. An 1-Aminocyclopropane-1-carboxylate (ACC) deaminase- 
expressing endophyte increases plant resistance to flavescence dorée phytoplasma infection. Plant Biosyst 2017, 151, 331-340, https://doi.org/10.1080/11263504.2016.1174172.

13. Jiao, J.; Ma, Y.; Chen, S.; Liu, C.; Song, Y.; Qin, Y.; Yuan, C.; Liu, Y. Melatonin-Producing Endophytic Bacteria from Grapevine Roots Promote the Abiotic Stress-Induced Production of Endogenous Melatonin in Their Hosts. Front Plant Sci 2016, 7, 1387, https://doi.org/10.3389/fpls.2016.01387.

14. Salomon, M.V.; Bottini, R.; de Souza Filho, G.A.; Cohen, A.C.; Moreno, D.; Gil, M.; Piccoli, P. Bacteria isolated from roots and rhizosphere of Vitis vinifera retard water losses, induce abscisic acid accumulation and synthesis of defense-related terpenes in vitro cultured grapevine. Physiol Plant 2014, 151, 359-374.

15. Ait Barka, E.; Nowak, J.; Clément, C. Enhancement of chilling resistance of inoculated grapevine plantlets with a plant growth-promoting rhizobacterium, Burkholderia phytofirmans strain PsJN. Appl Environ Microbiol 2006, 72, 7246-7252, https://doi.org/10.1128/AEM.01047-06.

16. Theocharis, A.; Bordiec, S.; Fernandez, O.; Paquis, S.; Dhondt-Cordelier, S.; Baillieul, F.; Clément, C.; Barka, E.A. Burkholderia phytofirmans PsJN primes Vitis vinifera L. and confers a better tolerance to low nonfreezing temperatures. Mol Plant-Microbe Interact 2012, 25, 241-249, https://doi.org/10.1094/MPMI05-11-0124.

17. Funes Pinter, I.; Salomon, M.V.; Berli, F.; Bottini, R.; Piccoli, P. Characterization of the As(III) tolerance conferred by plant growth promoting rhizobacteria to in vitro-grown grapevine. Appl Soil Ecol 2017, 109, 60-68, https://doi.org/10.1016/j.apsoil.2016.10.003.

18. Torres, N.; Goicoechea, N.; Zamarreño, A.M.; Carmen Antolín, M. Mycorrhizal symbiosis affects ABA metabolism during berry ripening in Vitis vinifera L. cv. Tempranillo grown under climate change scenarios. Plant Sci 2018, 274, 383-393, https://doi.org/10.1016/j.plantsci.2018.06.009.

19. Matthews, M.C.; Mostert, D.; Ndayihanzamaso, P.; Rose, L.J.; Viljoen, A. Quantitative detection of economically important Fusarium oxysporum f. sp. cubense strains in Africa in plants soil and water. PLoS One 2020, 15, e0236110, http://doi:10.1371/journal.pone.0236110.

20. Lecomte, C.; Alabouvette, C.; Edel-Hermann, V.; Robert, F.; Steinberg, C. Biological control of ornamental plant diseases caused by Fusarium oxysporum: A review. Biol Control 2016, 101, 17-30, http://doi:10.1016/j.biocontrol.2016.06.004

21. Nelson, N. A Photometric Adaptation Of The Somogyi Method For The Determination Of Glucose. Journal of biological Chemistry 1944, 153, 375-380.

22. Zeppenfeld, T.; Balkenhol, N.; Kóvacs, K.; Carminati, A. Rhizosphere hydrophobicity: A positive trait in the competition for water. PLoS One 2017, 12, https://doi.org/10.1371/journal.pone.0182188.

23. Vives-Peris, V.; de Ollas, C.; Gómez-Cadenas, A.; Pérez-Clemente, R.M. Root exudates: from plant to rhizosphere and beyond. Plant Cell Rep 2020, 39, 3-17, https://doi.org/10.1007/s00299-019-02447-5.

24. Cazorla, F.M.; Romero, D.; Pérez-García, A.; Lugtenberg, B.J.J.; Vicente, A. De; Bloemberg, G. Isolation and characterization of antagonistic Bacillus subtilis strains from the avocado rhizoplane displaying biocontrol activity. J Appl Microbiol 2007, 103, 1950-1959.

25. Stein, T. Bacillus subtilis antibiotics: Structures, syntheses and specific functions. Mol Microbiol 2005, 56, 845-857.

26. Collins, D.P.; Jacobsen, B.J. Optimizing a Bacillus subtilis isolate for biological control of sugar beet cercospora leaf spot. Biol Control 2003, 26, 153-161, https://doi.org/10.1016/S1049-9644(02)00132-9.

27. Akinrinlola, R.J.; Yuen, G.Y.; Drijber, R.A.; Adesemoye, A.O. Evaluation of Bacillus Strains for Plant Growth Promotion and Predictability of Efficacy by In Vitro Physiological Traits. Int J Microbiol 2018, 2018, https://doi.org/10.1155/2018/5686874.

28. Vafadar, F.; Amooaghaie, R.; Otroshy, M. Effects of plant-growth-promoting rhizobacteria and arbuscular mycorrhizal fungus on plant growth, stevioside, NPK, and chlorophyll content of Stevia rebaudiana. J Plant Interact 2014, 9, 128-136, https://doi.org/10.1080/17429145.2013.779035.

29. Nanjundappa, A.; Bagyaraj, D.J.; Saxena, A.K.; Kumar, M.; Chakdar, H. Interaction between arbuscular mycorrhizal fungi and Bacillus spp. In soil enhancing growth of crop plants. Fungal Biol Biotechnol 2019, 6, 1-10, https://doi.org/10.1186/s40694-019-0086-5.

30. Bianciotto, V.; Minerdi, D.; Perotto, S.; Bonfante, P. Cellular interactions between arbuscular mycorrhizal fungi and rhizosphere bacteria. Protoplasma 1996, 193, 123-131, https://doi.org/10.1007/BF01276640.

31. Johansson, J.F.; Paul, L.R.; Finlay, R.D. Microbial interactions in the mycorrhizosphere and their significance for sustainable agriculture. FEMS Microbiol Ecol 2004, 48, 1-13, https://doi.org/10.1016/j.femsec.2003.11.012.

32. Tylka, G.L. Axenic Germination of Vesicular-Arbuscular Mycorrhizal Fungi: Effects of Selected Streptomyces Species. Phytopathology 1991, 81.

33. Rainey, P.B.; Cole, A.L.J.; Fermor, T.R.; Wood, D.A. A model system for examining involvement of bacteria in basidiome initiation of Agaricus bisporus. Mycol Res 1990, 94, 191-195, https://doi.org/10.1016/S0953-7562(09)80612-6.

34. Warmink, J.A.; Van Elsas, J.D. Migratory response of soil bacteria to Lyophyllum sp. strain Karsten In soil microcosms. Appl Environ Microbiol 2009, 75, 2820-2830, https://doi.org/10.1128/AEM.02110-08. 
35. Citterio, B.; Malatesta, M.; Battistelli, S.; Marcheggiani, F.; Baffone, W.; Saltarelli, R.; Stocchi, V.; Gazzanelli, G. Possible involvement of Pseudomonas fluorescens and Bacillaceae in structural modifications of Tuber borchii fruit bodies. Can J Microbiol 2001, 47, 264-268, https://doi.org/10.1139/w01-005.

36. García-Gutiérrez, M.S.; Ortega-Álvaro, A.; Busquets-García, A.; Pérez-Ortiz, J.M.; Caltana, L.; Ricatti, M.J.; Brusco, A.; Maldonado, R.; Manzanares, J. Synaptic plasticity alterations associated with memory impairment induced by deletion of CB2 cannabinoid receptors. Neuropharmacology 2013, 73, 388-396, https://doi.org/10.1016/j.neuropharm.2013.05.034.

37. Jayaraj, J.; Yi, H.; Liang, G.H.; Muthukrishnan, S.; Velazhahan, R. Foliar application of Bacillus subtilis AUBS1 reduces sheath blight and triggers defense mechanisms in rice. Journal of Plant Diseases and Protection 2004, 111, 115-125, https://doi.org/10.1007/bf03356138.

38. Shailendra Singh, G.G. Plant Growth Promoting Rhizobacteria (PGPR): Current and Future Prospects for Development of Sustainable Agriculture. J Microb Biochem Technol 2015, 07, 96-102, https://doi.org/10.4172/1948-5948.1000188.

39. Zakry, F.A.A.; Shamsuddin, Z.H.; Abdul Rahim, K.; Zawawi Zakaria, Z.; Abdul Rahim, A. Inoculation of Bacillus sphaericus UPMB-10 to Young Oil Palm and Measurement of Its Uptake of Fixed Nitrogen Using the $15 \mathrm{~N}$ Isotope Dilution Technique. Microbes Environ 2012, 27, 257-262, https://doi.org/10.1264/jsme2.ME11309.

40. Desoky, E. S. M.; Saad, A. M.; El-Saadony, M. T.; Merwad, A. R. M.; Rady, M. M. Plant growth-promoting rhizobacteria: Potential improvement in antioxidant defense system and suppression of oxidative stress for alleviating salinity stress in Triticum aestivum (L.) plants. Biocatalysis and Agricultural Biotechnology 2020, 30, 101878, http:// doi:10.1016/j.bcab.2020.101878.

41. Lushchak, V.I. Oxidative Stress in Yeast. Biochem 2010, 75, 281-296, https://doi.org/10.1134/S0006297910030041.

42. Vacheron, J.; Desbrosses, G.; Bouffaud, M.L.; Touraine, B.; Moënne-Loccoz, Y.; Muller, D.; Legendre, L.; Wisniewski-Dyé, F.; Prigent-Combaret, C. Plant growth-promoting rhizobacteria and root system functioning. Front Plant Sci 2013, 4, https://doi.org/10.3389/fpls.2013.00356. 